\title{
The Possible Cardio-Reno- Protective Effects of Vanillin on Isopretrenol- Induced Myocardial Infarction in Rats
}

\author{
Ekram N. Abd Al Haleem, Hala M. Ali ${ }^{1}$ and Amany A. Eissa ${ }^{2}$
}

${ }^{1}$ Department of Pharmacology and Toxicology, Faculty of Pharmacy for Girls, Al-Azhar University, Egypt.

2 Department of Pharmacology and Toxicology, Faculty of Pharmacy, Helwan University, Egypt.

\begin{abstract}
Myocardial infarction (MI) continues to be a major public health problem in the world. Vanillin is a natural phenolic compound that possesses significant anti-oxidant and anti-inflammatory activities. The present study aimed to investigate the effects of pretreatment with vanillin $(150 \mathrm{mg} / \mathrm{kg}$, p.o. $)$ and vanillin $(300 \mathrm{mg} / \mathrm{kg}$, p.o.) on isoprenaline-induced MI in rats. Markers chosen to assess cardiac damage included serum activity of creatine kinase-MB (CK-MB) and lactate dehydrogenase (LDH), in addition to serum level of cardiac troponin-I (cTn-I), as well as antioxidant activity of cardiac catalase (CAT) as well as cardiac contents of RGH, lipid peroxides, and nitrite. Furthermore Electrocardiograph (ECG) monitoring and histological examinations of cardiac tissues were done. In addition markers chosen to assess renal impairment included serum and urine levels of creatinin, blood urea nitrogen (BUN), also creatinine clearance (Ccr), urea clearance (Ucr) and glomerular filteration rate (GFR) were assessed. In addition, antioxidant activity of renal CAT and renal contents of RGH, lipid peroxides, and nitrite. Furthermore, histological examinations of renal tissues were done. Isoprenaline increased serum CK-MB and LDH activity and cTn-I level, cardiac and renal oxidative stress biomarkers. In addition, it produced ST-segment elevation and degenerative changes in heart and renal tissues. Pretreatment with vanillin in previous doses significantly suppressed isoprenalineinduced pathological changes, as the elevated levels of cTn-I, LDH and CK-MB in serum coupled with reduction in cardiac and renal oxidative stress markers. Moreover marked improvement in ECG and histopathologic alterations in both cardiac and renal tissues were produced. In conclusion, vanillin can be regarded as a promising cardio- and reno- protective natural agent in MI.
\end{abstract}

Keywords Myocardial infarction, renal impairment, vanillin, oxidative stress.

\footnotetext{
Introduction

Acute myocardial infarction (AMI) continues to be a health problem causing mortality and morbidity despite clinical care and public concern (Ruff and Braunwald, 2011). It is well known that MI is a common symptom of myocardial ischemia, and occurs when cardiac injury surpasses a critical threshold, resulting in mortal cardiac damage (Kim, 2012). In MI, reactive oxygen species (ROS) are the primary components of oxidative damage of cardiomyocytes (Dhalla et al., 2000). Renal dysfunction is a strong independent predictor of cardiovascular outcomes and mortality in the general population (Go et al., 2004) after MI (Lekston et al., 2009 and Amin et al., 2012).

To study possible protective effects of drugs on the myocardial injury from AMI, a widely used experimental model is the induction of MI by means of the receiving isoproterenol in rats, since this substance causes a myocardial damage similar to the one observed in AMI in humans (Ithayarasi and Devi, 1997). Several mechanisms proposed to explain the
}

isoproterenol-induced myocardial harm, one might say: an unbalance between oxygen supply to and demand from cardiomyocytes inwardly, which is related to myocardial hyperfunction due to increase both in chronotropism and inotropism as well as to hypotension in the coronary bed (Yeager and Whitehurst, 1982). Secondly, it is also claimed that there is an elevation of $\mathrm{Ca}^{++}$overcharge inside the cell (Bloom and Davis, 1972), in addition, that ion is related to the activation of the adenylate cyclase enzyme and the depletion of ATP levels on the course of the events (Bhagat et al., 1976). Eventually, there is an oxidative stress augmentation because of several metabolic products originated from isoproterenol (Singal et al., 1982). Compromised antioxidant defense leads to metabolic and functional impairment and membrane permeability changes consequent to lipid peroxidation and ultimately irreversible damage to the myocyte membrane (Zhang et al., 2014). 
Myocardial infarction (MI) is a major form of ischemic heart disease, characterized by an imbalance of coronary blood supply and myocardial demand which results in ischemia and myocardial death. Experimental and clinical studies have shown that, during ischemic injury, produced oxidative stress plays a key role in the development of MI (Tullio et al., 2013). In ischemic tissues, the oxygen-free radicals have been implicated in oxidative chain reactions, which damage the cell membrane and subcellular structures containing phospholipids and proteins. These reactions further cause phospholipid peroxidation and subsequently lead to functional, structural, and metabolic alterations in the heart (Tappia et al., 2001). The central role of ROS in the pathophysiology of MI has been confirmed by the ability of antioxidants to reduce ischemic injury in the animal model of isoproterenol- induced MI (Ojha et al., 2012). A large number of epidemiological, clinical, and experimental studies have demonstrated that the use of antioxidants as a preventive approach may limit the infarct size and attenuate myocardial dysfunction as well as slowing down the progression and consequences of MI (Agrawal et al., 2014). Antioxidants not only suppress the formation of ROS and free radical generation and or augmentation of endogenous antioxidant enzymes but also modulate heart function (Ertracht et al., 2014).

Numerous previous studies have shown that antioxidants may inhibit the progression of cardiac ischemia (Visioli et al., 2000). Accordingly, many natural antioxidants are recognized to have potential as herbal medicines for reducing the occurrence of cardiovascular diseases (Ignarro et al., 2007). Vanillin, for example, is a chemical compound that confers the smell and flavor of vanilla, is used as a sleep prevention agent and an aphrodisiac (Bythrow, 2005). Functional uses of vanillin indicate that it exhibits chemopreventive effects in multiorgan carcinogenesis models in rats (Akagi et al., 1995) and prevents the invasion and migration of cancer cells (Cheng et al., 2008); it can also be used to treat sickle cell anemia (Zhang et al., 2004). Besides, vanillin has been shown to inhibit lipopolysaccharide-stimulated NF-KB activation and cyclooxygenase-2 gene expression in murine macrophages (Murakami et al., 2007). In addition it has anti-oxidant, anti-inflammatory and hepatoprotective effects against $\mathrm{CCl} 4$-induced acute liver injury in adult rats (Makni et al., 2011).

In the present study, we investigated the cardio- and reno- protective effect of vanillin against isoproterenol-induced myocardial injury, a clinically relevant animal model, by measuring the markers of myocyte injury, cardiac and renal biochemical markers, antioxidant defense system, and echo- cardiogram (ECG) parameters. Furthermore, to support our findings, we also examined the effects of vanillin on histopathological changes in the myocardium and kidney tissues.

\section{Materials and methods Drugs and chemicals}

Chemicals: All chemicals used in this study were analytically pure and purchased from Sigma-Aldrich Chemical Co., (St Louis, MO, USA), isoprenaline which was used for MI induction and vanillin which was used for protection were in powder form.

\section{Animals}

Eighty four male Wister rats weighed $150-180 \mathrm{~g}$ were obtained from the Holding Company for Biological Products \& Vaccines VACCERA, Egypt. The normal chow was acquired from Meladco for Animal Food, Egypt. Pellets and tap water were provided ad libitum. Temperature was maintained at $25^{\circ} \mathrm{C}$. A $12 / 12 \mathrm{~h}$ light/dark cycle was maintained. Rats were allowed at least 1 week to acclimatize to the lab conditions. All procedures were done according to guidelines of Ethical Committee, Faculty of Pharmacy, Al-Azhar University.

\section{Experimental design}

Rats were divided into six equal groups, the first group acted as control (-ve control). The second was the MI group, received isoprenaline powder which was dissolved in normal saline in a dose of $85 \mathrm{mg} / \mathrm{kg}$, subcutaneously (S.C.) for two consecutive days at 24 hrs interval. and used as +ve control (Ojha et al., 2008). The third group received vanillin powder that was prepared in a suspension form in distilled water, by using tween 80 as a suspending agent, in a dose of 150 $\mathrm{mg} / \mathrm{kg}$, orally by gavage (P.O.) for five days (Ket et al., 2010). The fourth group received vanillin in a dose of $150 \mathrm{mg} / \mathrm{kg}$, P.O. for five days followed by isoprenaline in a dose of $85 \mathrm{mg} / \mathrm{kg}$, S.C. for two successive days. The fifth group received vanillin in a dose of 300 $\mathrm{mg} / \mathrm{kg}$, P.O. for five days (Ket et al., 2010), and the sixth group received vanillin in a dose of $300 \mathrm{mg} / \mathrm{kg}$, P.O. for five days followed by isoprenaline in a dose of $85 \mathrm{mg} / \mathrm{kg}$, S.C. for two successive days.

Twenty four hours after the last dose of isopretenol, urine was collected in a metabolic cage for determination of Ccr, Ucr and Ucr, then the rats were anaesthetized by using urethane dissolved in saline $(0.9 \% \mathrm{NaCl}$ in a dose of $1.2 \mathrm{~g} / \mathrm{kg}$, intraperitoneally (I.P.) (Karl et al., 1993) for the ECG estimation. Blood was collected from the retro-orbital venous plexus, and allowed to clot and serum was separated by centrifugation at $3000 \mathrm{~g}$ for $15 \mathrm{~min}$ for biochemical assessment. Rats were then anaesthetized and sacrificed by cervical dislocation (painless death ethics). The hearts and kidneys were dissected out. The heart was weighed and immersed in ice-cold saline. The hearts and kidneys from two rats were fixed in $10 \%$ buffered formalin for staining with haematoxylin and eosin and undergo histopathological examination (Banchroft et al., 1996). Heart and kidney tissues were homogenized in saline, centrifuged, and the supernatant fluid was used for assessment of oxidative stress biomarkers using Shimadzu Spectrophotometer UV-1201 (Japan).

\section{Hemodynamic assessments}

Anesthetized rats were placed in the supine position on a board and ECG was recorded continuously with standard artifact free lead II (right forelimb to left hind limb). Needle electrodes were inserted subcutaneously into paw pads of each rat, and connected to Biocare ECG 101 (Shenzhen Biocare Electronics Co., Ltd., China). The ECG was measured to determine duration 
and amplitude of the P wave, QRS complex, and ST segment alterations.

Heart index $=($ heart weight/body weight $) \times 100$.

\section{Biochemical analysis}

\section{Cardio-toxicity markers}

Serum CK-MB and LDH activities were determined according to standard methods using available commercial kits (Spectrum diagnostics, Cairo, Egypt), cTn-I, was determined using an enzyme-linked immunosorbent assay (ELISA) developed by Life Diagnostics Inc. West Chester PA, USA, according to the manufacturer's instructions.

\section{Kidney function tests}

Serum concentrations of BUN and creatinine were estimated. In addition concentrations of urea and creatinine in urine were measured, using standard diagnostic kits (Quimica Clinica Aplicada s.a., Amposta, Spain).

Determination of glomerular filtration rate (GFR): was calculated according to the following equation (Pestel et al., 2007).

$\mathrm{GFR}=\sqrt{ }$ Creatinine Clearance $(\mathrm{Ccr}) \times$ Urea Clearance (Ucr)

Determination of creatinine clearance $\left(\mathrm{C}_{\mathrm{Cr}}\right)$ : was calculated on the basis of urinary $\mathrm{Cr}$, serum $\mathrm{Cr}$, urine volume body weight, using the equation shown below (Kim et al., 2004).

$\operatorname{Ccr}(\mathrm{ml} / \mathrm{min} / \mathrm{kg}$ body weight $)=$ (urinary $\mathrm{Cr}$ $(\mathrm{mg} / \mathrm{dl}) \mathrm{x}$ urine volume $(\mathrm{ml}) /$ serum $\mathrm{Cr}(\mathrm{mg} / \mathrm{dl})) \mathrm{x}$ (1000/body weight $(\mathrm{g}) \times(1 / 1440$ (min))

Determination of urea clearance $(\mathrm{Ucr})=$ Urine urea $(\mathrm{mg} / \mathrm{dl}) \times \mathrm{V}(\mathrm{ml} / \mathrm{min}) /$ Plasma urea $(\mathrm{mg} / \mathrm{dl})$ (Pestel et al., 2007).

Assessment of cardiac and renal oxidative stress markers and antioxidant enzymes activities:

Catalase (CAT) activities were assessed according to the manufacturer's instructions of available kits (Trevigen, Inc., USA), (Aebi, 1984).

Determination of reduced glutathione $(\mathrm{RGH})$ level: RGH level in cardiac and renal tissues homogenates was measured by the method of Ellman (1959). Trichloroacetic acid (5\%) was added to adequate dilution of tissue homogenates $(0.5 \mathrm{ml})$ to precipitate the protein content in the samples. Then, this mixture was centrifuged at $10,000 \mathrm{~g}, 5 \mathrm{~min}$ and the supernatant was recovered. Finally, 5, 5'-dithiobis (2-nitrobenzoic acid) solution was added to the reaction mixtures, and the absorbance was recorded at $412 \mathrm{~nm}$ using spectrophotometer.

Determination of lipid peroxide level: Lipid peroxidation was determined by estimating the level of thiobarbituric acid reactive substances measured as malondialdehyde (MDA), according to the method of Uchiyama and Mihara (1978). Briefly, the reaction mixture $(0.5 \mathrm{ml}$ homogenate $+2.5 \mathrm{ml} 20 \%$ trichloroacetic acid $+1.0 \mathrm{ml} 0.6 \%$ thiobarbituric acid) was heated for $20 \mathrm{~min}$ in a boiling water bath followed by cooling and addition of $4 \mathrm{ml} \mathrm{n}$-butanol with shaking. The alcohol layer was separated by centrifugation at $2000 \mathrm{~g}$ for $10 \mathrm{~min}$ and absorbance was measured at $535 \mathrm{~nm}$. The results were expressed as nmol MDA/g wet tissue using 1,1,3,3tetraethoxypropane as standard.
Determination of Nitric oxide (NO) content: Using the Griess reaction (Griess, 1879), the accumulated nitrite was measured in the cardiac and renal tissue homogenate as an indicator of $\mathrm{NO}$ production. Briefly, $0.3 \mathrm{ml}$ of colon homogenate was mixed with an equal volume of $1 \%(\mathrm{w} / \mathrm{v})$ sulfanilamide [in 5\% (v/v) phosphoric acid] and $0.1 \%(\mathrm{w} / \mathrm{v}) \mathrm{N}-1-$ naphtylethylenediamine dihydrochloride, and incubated at room temperature for $10 \mathrm{~min}$. The absorbance at 548 $\mathrm{nm}$ was measured. Sodium nitrite serial dilution standard curve was used to calculate concentrations in the samples. All samples were analyzed in triplicate.

Cardiac and renal histopathological analysis: Specimens from cardiac and renal tissues were cleared in xylene and embedded in paraffin at 56 degrees in hot air oven for twenty four hours. Paraffin bees wax tissue blocks were prepared for sectioning at 4 microns thickness and stained by hematoxylin and eosin stains for histopathological examination under light microscope (Banchroft et al., 1996).

\section{Statistical analysis}

Results were expressed as Mean \pm Standered Error of the Mean (SEM) of six animals and the different groups were compared using one-way analysis of variance followed by Tukey-Kramer test for multiple comparisons. Prism (version5) was used.

\section{Results}

Protective effects of vanillin on electro-cardio graphic changes in isopretrenol- induced myocardial infarction in rats

Figure (1) showing lead II ECG trace pattern of: (A) normal rat showing regular ECG pattern with defined $\mathrm{P}, \mathrm{QRS}$, and $\mathrm{T}$ waves, (B) isoprenaline treated rat showing positive $\mathrm{T}$ wave, $\mathrm{ST}$ segment elevation, and decreased $\mathrm{R}$ wave amplitude, $(\mathbf{C})$ vanillin $(150 \mathrm{mg} / \mathrm{kg})$ treated rat showing regular ECG pattern, (D) MI + vanillin $(150 \mathrm{mg} / \mathrm{kg})$ pretreated rat showing a marked decrease in ST segment elevation and an increase in R wave amplitude; (E) vanillin $(300 \mathrm{mg} / \mathrm{kg})$ treated rat showing regular ECG pattern and (F) MI+ Vanillin $(300 \mathrm{mg} / \mathrm{kg})$ pretreated rat showing a decrease in ST segment elevation and an increase in $R$ wave amplitude.

Protective effects of vanillin on heart index in isopretrenol- induced myocardial infarction in rats:

Our findings in table (3) indicated that in MI group heart index was increased by $43.29 \%$ compared with the control group, (the ratio of heart/body weight is an index of cardiac hypertrophy) while pretreatment of MI with vanillin in both doses $(150 \mathrm{mg} / \mathrm{kg}$ and $300 \mathrm{mg} / \mathrm{kg}$ ) significantly reduced cardiac hypertrophy as evidenced by reduction of heart/body weight by $26.20 \%$ and $13.10 \%$ respectively compared with MI group.

\section{Protective effects of vanillin on serum cardiac} biomarkers in isopretrenol- induced myocardial infarction in rats

Our findings in table (1) indicated that in MI group all cardiac biomarkers cTn-I, CK-MB and LDH were increased by $51.4 \%, 135.5 \%$ and $187.5 \%$, respectively compared with control group. While pretreatment of MI with vanillin in both doses $(150 \mathrm{mg} / \mathrm{kg}$ and 
$300 \mathrm{mg} / \mathrm{kg}$ ), significantly reduced cardiac biomarkers cTn-I by $47.70 \%$ and $74.43 \%$, respectively, CK-MB by $188.82 \%$ and $140.74 \%$, respectively and $\mathrm{LDH}$ by $43.93 \%$ and $48.52 \%$, respectively, compared with MI group. In addition pretreatment of MI with vanillin in a dose of $300 \mathrm{mg} / \mathrm{kg}$, significantly reduced cTn-I and CKMB by $51.11 \%$ and $25.46 \%$, respectively compared with MI group pretreated with vanillin in a dose of $150 \mathrm{mg} / \mathrm{kg}$.

Protective effects of vanillin on kidney function tests in isopretrenol- induced myocardial infarction in rats

Our findings in table (2) indicated that in MI group serum renal biomarkers BUN and serum creatinine were increased by $67.92 \%, 61.76 \%$ respectively compared with control group. While pretreatment of MI with vanillin in both doses $(150 \mathrm{mg} / \mathrm{kg}$ and $300 \mathrm{mg} / \mathrm{kg}$ ), significantly reduced BUN by $30.22 \%$ and $34.49 \%$, respectively and serum creatinine by $62.98 \%$ and $63.55 \%$, respectively, compared with MI group.

In addition to that, our findings in table (2) indicated that MI induced significant decrease in urine volume, but significantly increased urinary creatinine and urinary urea by $65.1 \%, 76.43 \%$ and $64.72 \%$, respectively compared with control group. While pretreatment of MI with vanillin in both doses $(150 \mathrm{mg} / \mathrm{kg}$ and $300 \mathrm{mg} / \mathrm{kg})$, significantly increased urine volume by $32.09 \%$ and $44.85 \%$, respectively and significantly decreased urinary creatinine by $33.62 \%$ and $38.00 \%$ respectively. Also they induced significant decrease in urinary urea by $26.54 \%$ and $37.69 \%$ respectively, compared with MI group.

Protective effects of vanillin on glomerular filteration rate (GFR) and renal clearance of creatinine (Ccr) and urea (Ucr) in isopretrenolinduced myocardial infarction in rats

Our findings in figure (2) indicated that MI induced significant decrease in GFR, Ccr and Ucr by $33.25 \%$, $33.93 \%$ and $36.21 \%$, respectively compared with control group. While pretreatment of MI with vanillin in both doses $(150 \mathrm{mg} / \mathrm{kg}$ and $300 \mathrm{mg} / \mathrm{kg}$ ), significantly increased GFR by $42.12 \%$ and $38.98 \%$, respectively, Ccr by $49.33 \%$ and $49.61 \%$, respectively and Ucr by $42.31 \%$ and $38.28 \%$, respectively compared with MI group.

Protective effects of vanillin on cardiac and renal catalase (CAT) activity in isopretrenolinduced myocardial infarction in rats

Our findings in table (3 and 4) indicated that in MI group cardiac and renal CAT was decreased by $36.20 \%$ and $34.88 \%$, respectively compared with control group. While pretreatment of MI with vanillin in a dose of $(150 \mathrm{mg} / \mathrm{kg})$, significantly increased cardiac CAT by $56.97 \%$ and renal CAT by $46.17 \%$, respectively compared with MI group. While pretreatment of MI with vanillin in a dose of $300 \mathrm{mg} / \mathrm{kg}$, didn't produce any significant variation in cardiac or renal CAT compared with MI group. In addition pretreatment of MI with vanillin in a dose of $150 \mathrm{mg} / \mathrm{kg}$, significantly increase cardiac CAT by $54.21 \%$ and renal CAT by $53.21 \%$, respectively compared with $\mathrm{MI}$ group pretreated with vanillin in a dose of $300 \mathrm{mg} / \mathrm{kg}$.
Protective effects of vanillin on cardiac and renal reduced glutathione (RGH) content in isopretrenol-induced myocardial infarction in rats

Our findings in table (3 and 4) indicated that in MI group cardiac and renal $\mathrm{RGH}$ were decreased by $36.25 \%$ and $16.89 \%$ respectively compared with control group. While pretreatment of MI with vanillin in both doses $(150 \mathrm{mg} / \mathrm{kg}$ and $300 \mathrm{mg} / \mathrm{kg}$ ), significantly increased cardiac RGH by $56.88 \%$ and $17.56 \%$, respectively and renal RGH by $26.36 \%$ and $24.50 \%$, respectively, and compared with $\mathrm{MI}$ group. In addition pretreatment of MI with vanillin in a dose of $150 \mathrm{mg} / \mathrm{kg}$, significantly increase renal RGH by $33.44 \%$ compared with MI group pretreated with vanillin in a dose of $300 \mathrm{mg} / \mathrm{kg}$.

Protective effects of vanillin on cardiac and renal malondialdehyde (MDA) content in isopretrenol-induced myocardial infarction in rats

Our findings in table (3 and 4) revealed that in MI group cardiac and renal MDA were increased by $67.68 \%, 63.42 \%$ respectively compared with control group. While pretreatment of MI with vanillin in both doses $(150 \mathrm{mg} / \mathrm{kg}$ and $300 \mathrm{mg} / \mathrm{kg})$, significantly decreased cardiac MDA by $35.18 \%$ and $29.84 \%$, respectively and renal MDA by $56.83 \%$ and $28.90 \%$, respectively, and compared with $\mathrm{MI}$ group.

Protective effects of vanillin on cardiac and renal nitric oxide (NO) content in isopretrenolinduced myocardial infarction in rats

Our findings in table (3 and 4) revealed that in MI group cardiac and renal NO were increased by $109.67 \%$, 51.7\% respectively compared with control group. While pretreatment of MI with vanillin in both doses $(150 \mathrm{mg} / \mathrm{kg}$ and $300 \mathrm{mg} / \mathrm{kg})$, significantly decreased cardiac NO by $29.40 \%$ and $51.58 \%$, respectively and renal NO by $34.46 \%$ and $37.40 \%$, respectively, compared with MI group.

Protective effects of vanillin on cardiac histopathological changes in isopretrenolinduced myocardial infarction in rats

Figure (3) Photomicrograph of longitudinal section from heart of rat in (A) control group showing no abnormal histopathological findings in myocardial muscle bundles, (B) MI group showing focal inflammatory cells infiltration detected in the degenerated (myd) and hyalinized (myh) myocardial bundles, while $(\mathbf{C})$ vanillin $(150 \mathrm{mg} / \mathrm{kg})$ group showing no abnormal histopathological alterations in myocardial muscle bundles, while (D) MI + vanillin $(150 \mathrm{mg} / \mathrm{kg})$ group showing focal inflammatory cells infiltration in the degenerated myocardium $(m y d)$. In addition (E) vanillin $(300 \mathrm{mg} / \mathrm{kg})$ group, the myocardial bundles showed mild congestion in the blood vessels (v), and (F) MI + vanillin (300 mg/kg) Oedema (o) with inflammatory cells (m) infiltration were detected in the subendocardium tissue. 
Protective effects of vanillin on renal histopathological changes in isopretrenolinduced myocardial infarction in rats

Figure (4) Photomicrograph of longitudinal section from kidney of rat in (A) control group showing no abnormal histopathological findings observed in the glomeruli and tubules at the cortex as well as in the tubules at the corticomedullary junction, (B) MI group showing swelling and vacuolization in the lining endothelium of the glomerular tufts (g) associated with degenerative change in the lining epithelium of the tubules at the cortex (d), while (C) vanillin (150 $\mathrm{mg} / \mathrm{kg}$ ) group showing no abnormal histopathological alteration, while (D) MI + vanillin ( $150 \mathrm{mg} / \mathrm{kg})$ group showing perivascular inflammatory cells aggregations surrounding the congested blood vessels (v). In addition (E) in vanillin $(300 \mathrm{mg} / \mathrm{kg})$ group, mild congestion was detected in the tufts of the glomeruli (g), finally (F) MI + vanillin $(300 \mathrm{mg} / \mathrm{kg}$ ) no abnormal histopathological alterations were recorded.

Table (1): Protective effects of vanillin on serum cardiac biomarkers in isopretrenol- induced myocardial infarction in rats

\begin{tabular}{|c|c|c|c|c|c|c|}
\hline Parameter & Control & MI & $\begin{array}{c}\text { Vanillin } \\
(150 \mathrm{mg} / \mathrm{kg})\end{array}$ & $\begin{array}{c}\text { MI+Van } \\
(150 \mathrm{mg} / \mathrm{kg})\end{array}$ & $\begin{array}{c}\text { Vanillin } \\
\text { (300mg/kg) }\end{array}$ & $\begin{array}{c}\text { MI+Van } \\
(300 \mathrm{mg} / \mathrm{kg})\end{array}$ \\
\hline $\begin{array}{c}\text { cTn-I } \\
(\mathrm{ng} / \mathrm{dl})\end{array}$ & $\begin{array}{c}0.776 \\
\pm \\
0.042 \\
\end{array}$ & $\begin{array}{c}8.357 \\
\pm \\
0.261^{\mathrm{a}} \\
\end{array}$ & $\begin{array}{c}1.168 \\
\pm \\
0.0149^{b} \\
\end{array}$ & $\begin{array}{c}4.367 \\
\pm \\
0.272^{\mathrm{a}, \mathrm{b}, \mathrm{c}} \\
\end{array}$ & $\begin{array}{c}1.550 \\
\pm \\
0.028^{\mathrm{a}, \mathrm{b}, \mathrm{d}} \\
\end{array}$ & $\begin{array}{c}2.135 \\
\pm \\
0.122^{\mathrm{a}, \mathrm{b}, \mathrm{c}, \mathrm{d}} \\
\end{array}$ \\
\hline $\begin{array}{c}\text { Serum CK-MB } \\
(\mathrm{ng} / \mathrm{dl})\end{array}$ & $\begin{array}{c}2.045 \\
\pm \\
0.198 \\
\end{array}$ & $\begin{array}{c}16.97 \\
\pm \\
0.713^{\mathrm{a}} \\
\end{array}$ & $\begin{array}{c}4.815 \\
\pm \\
0.192^{\mathrm{a}, \mathrm{b}}\end{array}$ & $\begin{array}{c}9.092 \\
\pm \\
0.324^{\mathrm{a}, \mathrm{b}, \mathrm{c}} \\
\end{array}$ & $\begin{array}{c}6.592 \\
\pm \\
0.143^{\mathrm{a}, \mathrm{b}, \mathrm{c}, \mathrm{d}} \\
\end{array}$ & $\begin{array}{c}6.777 \\
\pm \\
0.2552^{\mathrm{a}, \mathrm{b}, \mathrm{c}, \mathrm{d}} \\
\end{array}$ \\
\hline $\begin{array}{l}\text { Serum LDH } \\
(\mathrm{U} / \mathrm{L})\end{array}$ & $\begin{array}{l}99.70 \\
\pm \\
1.762\end{array}$ & $\begin{array}{c}287.5 \\
\pm \\
12.46^{\mathrm{a}}\end{array}$ & $\begin{array}{c}102.6 \\
\pm \\
6.008^{b}\end{array}$ & $\begin{array}{c}161.2 \\
\pm \\
14.81^{\mathrm{a}, \mathrm{b}, \mathrm{c}}\end{array}$ & $\begin{array}{c}105.3 \\
\pm \\
3.790^{\mathrm{b}, \mathrm{d}}\end{array}$ & $\begin{array}{c}148.0 \\
\pm \\
14.8^{\mathrm{a}, \mathrm{b}, \mathrm{c}, \mathrm{e}}\end{array}$ \\
\hline
\end{tabular}

Data are expressed as mean \pm SEM $(n=6), a, b, c, d$ or $e$ : indicates significantly different from the control, myocardial infarction, vanillin (150mg/kg), MI+ vanillin $(150 \mathrm{mg} / \mathrm{kg})$ and vanillin $(300 \mathrm{mg} / \mathrm{kg})$ group, respectively at $P<0.05$ using one way ANOVA followed by Tukey-Kramer as a post hoc test.

Table (2): Protective effects of vanillin on kidney function tests in isopretrenol- induced myocardial infarction in rats

\begin{tabular}{|c|c|c|c|c|c|c|}
\hline $\begin{array}{l}\text { Groups } \\
\text { Parameter }\end{array}$ & Control & MI & $\begin{array}{c}\text { Vanillin } \\
(150 \mathrm{mg} / \mathrm{kg})\end{array}$ & $\begin{array}{c}\text { MI+Van } \\
(150 \mathrm{mg} / \mathrm{kg})\end{array}$ & $\begin{array}{c}\text { Vanillin } \\
(300 \mathrm{mg} / \mathrm{kg})\end{array}$ & $\begin{array}{c}\text { MI+Van } \\
(300 \mathrm{mg} / \mathrm{kg})\end{array}$ \\
\hline $\begin{array}{c}\text { BUN } \\
(\mathrm{mg} / \mathrm{dl})\end{array}$ & $\begin{array}{c}20.39 \\
\pm \\
1.097 \\
\end{array}$ & $\begin{array}{c}34.24 \\
\pm \\
2.291^{\mathrm{a}} \\
\end{array}$ & $\begin{array}{c}22.26 \\
\pm \\
1.961^{\mathrm{b}} \\
\end{array}$ & $\begin{array}{c}23.89 \\
\pm \\
2.105^{\mathrm{b}} \\
\end{array}$ & $\begin{array}{c}18.70 \\
\pm \\
1.238^{\mathrm{b}} \\
\end{array}$ & $\begin{array}{c}22.36 \\
\pm \\
1.800^{\mathrm{b}} \\
\end{array}$ \\
\hline $\begin{array}{l}\text { Serum creatinine } \\
(\mathrm{mg} / \mathrm{dl})\end{array}$ & $\begin{array}{c}1.849 \\
\pm \\
0.08\end{array}$ & $\begin{array}{c}2.991 \\
\pm \\
0.08^{\mathrm{a}}\end{array}$ & $\begin{array}{c}1.856 \\
\pm \\
0.09^{\mathrm{b}}\end{array}$ & $\begin{array}{c}1.884 \\
\pm \\
0.06^{\mathrm{b}}\end{array}$ & $\begin{array}{c}1.832 \\
\pm \\
0.11^{\mathrm{b}}\end{array}$ & $\begin{array}{l}1.901 \\
\pm \\
1.10^{\mathrm{b}}\end{array}$ \\
\hline $\begin{array}{l}\text { Urine volume } \\
\qquad(\mathrm{ml})\end{array}$ & $\begin{array}{c}8.217 \\
\pm \\
0.18\end{array}$ & $\begin{array}{c}5.350 \\
\pm \\
0.24^{\mathrm{a}}\end{array}$ & $\begin{array}{c}8.417 \\
\pm \\
0.27^{\mathrm{b}}\end{array}$ & $\begin{array}{l}7.067 \\
\pm \\
0.20^{\mathrm{b}}\end{array}$ & $\begin{array}{c}8.533 \\
\pm \\
0.31^{\mathrm{b}, \mathrm{d}}\end{array}$ & $\begin{array}{l}7.750 \\
\pm \\
0.40^{\mathrm{b}}\end{array}$ \\
\hline $\begin{array}{l}\text { Urinary creatinine } \\
(\mathrm{mg} / \mathrm{dl})\end{array}$ & $\begin{array}{c}112.00 \\
\pm \\
3.88\end{array}$ & $\begin{array}{c}197.61 \\
\pm \\
12.22^{\mathrm{a}}\end{array}$ & $\begin{array}{c}110.30 \\
\pm \\
7.65^{b}\end{array}$ & $\begin{array}{c}131.17 \\
\pm \\
9.29^{\mathrm{b}}\end{array}$ & $\begin{array}{c}110.74 \\
\pm \\
5.86^{b}\end{array}$ & $\begin{array}{c}122.5 \\
\pm \\
6.95^{\mathrm{b}}\end{array}$ \\
\hline $\begin{array}{l}\text { Urinary urea } \\
\qquad(\mathrm{g} / \mathrm{dl})\end{array}$ & $\begin{array}{c}3.43 \\
\pm \\
0.26 \\
\end{array}$ & $\begin{array}{c}5.65 \\
\pm \\
0.44^{\mathrm{a}} \\
\end{array}$ & $\begin{array}{c}3.55 \\
\pm \\
0.31^{\mathrm{b}} \\
\end{array}$ & $\begin{array}{c}4.15 \\
\pm \\
0.40^{\mathrm{b}} \\
\end{array}$ & $\begin{array}{c}3.25 \\
\pm \\
0.26^{\mathrm{b}} \\
\end{array}$ & $\begin{array}{c}3.52 \\
\pm \\
0.34^{b}\end{array}$ \\
\hline
\end{tabular}

Data are expressed as mean \pm SEM $(n=6)$, a or $b$ : indicates significantly different from the control and myocardial infarction group, respectively at $P<0.05$ using one way ANOVA followed by Tukey-Kramer as a post hoc test.
Figure (2): Protective effects of vanillin on renal function tests in isopretrenol- induced myocardial

A) Protective effects of vanillin on GFR in isopretrenol- induced myocardial infarction in isopretrenol- induced myocardial infarction in rats isopretrenol- induced myocardial infarction in Data are expressed as mean \pm SEM $(n=6)$.

$\mathrm{a}, \mathrm{b}, \mathrm{c}, \mathrm{d}$ or e: indicates significantly different from $(150 \mathrm{mg} / \mathrm{kg})$, MI+ vanillin $(150 \mathrm{mg} / \mathrm{kg})$ and vanillin $(300 \mathrm{mg} / \mathrm{kg})$ group, respectively at $\mathrm{P}<0.05$ using one way ANOVA followed by Tukey-Kramer as a post hoc test. 
Table (3): Protective effects of vanillin on heart index and cardiac antioxidant parameters in isopretrenolinduced myocardial infarction in rats

\begin{tabular}{|c|c|c|c|c|c|c|}
\hline $\begin{array}{l}\text { Groups } \\
\text { Parameter }\end{array}$ & Control & MI & $\begin{array}{c}\text { Vanillin } \\
(150 \mathrm{mg} / \mathrm{kg})\end{array}$ & $\begin{array}{c}\text { MI+Van } \\
(150 \mathrm{mg} / \mathrm{kg})\end{array}$ & $\begin{array}{c}\text { Vanillin } \\
(300 \mathrm{mg} / \mathrm{kg})\end{array}$ & $\begin{array}{c}\text { MI+Van } \\
(300 \mathrm{mg} / \mathrm{kg})\end{array}$ \\
\hline $\begin{array}{c}\text { Heart } \\
\text { Index }(\mathrm{g})\end{array}$ & $\begin{array}{c}0.261 \\
\pm \\
0.004\end{array}$ & $\begin{array}{c}0.374 \\
\pm \\
0.004^{\mathrm{a}} \\
\end{array}$ & $\begin{array}{c}0.277 \\
\pm \\
0.006^{\mathrm{b}} \\
\end{array}$ & $\begin{array}{c}0.276 \\
\pm \\
0.008^{\mathrm{b}} \\
\end{array}$ & $\begin{array}{c}0.272 \\
\pm \\
0.002^{\mathrm{b}} \\
\end{array}$ & $\begin{array}{c}0.325 \\
\pm \\
0.007^{\mathrm{a}, \mathrm{b}, \mathrm{c}, \mathrm{d}, \mathrm{e}}\end{array}$ \\
\hline $\begin{array}{c}\text { CAT } \\
\text { (U/g tissue) }\end{array}$ & $\begin{array}{c}4.408 \\
\pm \\
0.338 \\
\end{array}$ & $\begin{array}{c}2.812 \\
\pm \\
0.206^{\mathrm{a}} \\
\end{array}$ & $\begin{array}{c}4.361 \\
\pm \\
0.243^{b}\end{array}$ & $\begin{array}{c}4.409 \\
\pm \\
0.334^{b}\end{array}$ & $\begin{array}{c}4.182 \\
\pm \\
0.466^{b}\end{array}$ & $\begin{array}{c}2.859 \\
\pm \\
0.088^{\mathrm{a}, \mathrm{c}, \mathrm{d}, \mathrm{e}} \\
\end{array}$ \\
\hline $\begin{array}{c}\text { RGH } \\
\text { (nmol/ g tissue) }\end{array}$ & $\begin{array}{c}7.86 \\
\pm \\
0.184 \\
\end{array}$ & $\begin{array}{c}5.01 \\
\pm \\
0.176^{\mathrm{a}} \\
\end{array}$ & $\begin{array}{c}10.92 \\
\pm \\
0.088^{\mathrm{a}, \mathrm{b}} \\
\end{array}$ & $\begin{array}{c}7.86 \\
\pm \\
0.317^{\mathrm{b}, \mathrm{c}} \\
\end{array}$ & $\begin{array}{c}7.48 \\
\pm \\
0.414^{\mathrm{b}, \mathrm{c}} \\
\end{array}$ & $\begin{array}{c}5.89 \\
\pm \\
0.134^{\mathrm{a}, \mathrm{c}, \mathrm{d}, \mathrm{e}} \\
\end{array}$ \\
\hline $\begin{array}{c}\text { MDA } \\
\text { ( nmol/g tissue) }\end{array}$ & $\begin{array}{c}42.42 \\
\pm \\
3.78 \\
\end{array}$ & $\begin{array}{l}71.13 \\
\pm \\
6.24^{\mathrm{a}} \\
\end{array}$ & $\begin{array}{c}39.03 \\
\pm \\
3.14^{\mathrm{b}}\end{array}$ & $\begin{array}{c}46.10 \\
\pm \\
1.80^{\mathrm{b}} \\
\end{array}$ & $\begin{array}{c}43.02 \\
\pm \\
4.27^{b}\end{array}$ & $\begin{array}{c}49.90 \\
\pm \\
4.02^{\mathrm{b}} \\
\end{array}$ \\
\hline $\begin{array}{l}\mathrm{NO} \\
(\mu \mathrm{M})\end{array}$ & $\begin{array}{c}21.70 \\
\pm \\
1.35\end{array}$ & $\begin{array}{c}45.50 \\
\pm \\
4.54^{\mathrm{a}}\end{array}$ & $\begin{array}{c}21.17 \\
\pm \\
1.19^{\mathrm{b}}\end{array}$ & $\begin{array}{c}32.12 \\
\pm \\
2.56^{\mathrm{b}}\end{array}$ & $\begin{array}{c}21.83 \\
\pm \\
2.10^{\mathrm{b}}\end{array}$ & $\begin{array}{c}22.03 \\
\pm \\
2.17^{\mathrm{b}}\end{array}$ \\
\hline
\end{tabular}

Data are expressed as mean $\pm \operatorname{SEM}(n=6), a, b, c, d$ or $e$ : indicates significantly different from the control, myocardial infarction, vanillin $(150 \mathrm{mg} / \mathrm{kg}), \mathrm{MI}+$ vanillin $(150 \mathrm{mg} / \mathrm{kg})$ and vanillin $(300 \mathrm{mg} / \mathrm{kg})$ group, respectively at $P<0.05$ using one way ANOVA followed by Tukey-Kramer as a post hoc test.

Table (4): Protective effects of vanillin on renal antioxidant parameters in isopretrenol-induced myocardial infarction in rats

\begin{tabular}{|c|c|c|c|c|c|c|}
\hline Groups & Control & MI & $\begin{array}{c}\text { Vanillin } \\
(150 \mathrm{mg} / \mathrm{kg})\end{array}$ & $\begin{array}{c}\text { MI+Van } \\
(150 \mathrm{mg} / \mathrm{kg})\end{array}$ & $\begin{array}{c}\text { Vanillin } \\
\text { (300mg/kg) }\end{array}$ & $\begin{array}{c}\text { MI+Van } \\
(300 \mathrm{mg} / \mathrm{kg})\end{array}$ \\
\hline $\begin{array}{c}\text { CAT } \\
\text { (U/g tissue })\end{array}$ & $\begin{array}{c}6.286 \\
\pm \\
0.17 \\
\end{array}$ & $\begin{array}{c}4.093 \\
\pm \\
0.09^{a} \\
\end{array}$ & $\begin{array}{c}6.520 \\
\pm \\
0.31^{\mathrm{b}} \\
\end{array}$ & $\begin{array}{c}5.983 \\
\pm \\
0.25^{\mathrm{b}} \\
\end{array}$ & $\begin{array}{l}6.146 \\
\pm \\
0.21^{\mathrm{b}} \\
\end{array}$ & $\begin{array}{c}3.905 \\
\pm \\
0.14^{\mathrm{a}, \mathrm{c}, \mathrm{d}, \mathrm{e}} \\
\end{array}$ \\
\hline $\begin{array}{c}\text { RGH } \\
\text { (nmol/g tissue) }\end{array}$ & $\begin{array}{c}19.35 \\
\pm \\
0.34\end{array}$ & $\begin{array}{c}16.08 \\
\pm \\
0.28^{\mathrm{a}}\end{array}$ & $\begin{array}{c}22.84 \\
\pm \\
0.26^{\mathrm{a}, \mathrm{b}}\end{array}$ & $\begin{array}{c}20.32 \\
\pm \\
0.36^{\mathrm{b}, \mathrm{c}}\end{array}$ & $\begin{array}{c}21.32 \\
\pm \\
0.79^{\mathrm{b}}\end{array}$ & $\begin{array}{c}20.02 \\
\pm \\
0.33^{\mathrm{b}, \mathrm{c}}\end{array}$ \\
\hline $\begin{array}{c}\text { MDA } \\
\text { (nmol/g tissue) }\end{array}$ & $\begin{array}{l}43.80 \\
\pm \\
4.09\end{array}$ & $\begin{array}{c}71.58 \\
\pm \\
4.69^{a}\end{array}$ & $\begin{array}{c}35.73 \\
\pm \\
3.37^{\mathrm{b}}\end{array}$ & $\begin{array}{c}30.90 \\
\pm \\
2.95^{\mathrm{b}}\end{array}$ & $\begin{array}{c}30.60 \\
\pm \\
1.76^{\mathrm{b}}\end{array}$ & $\begin{array}{c}51.47 \\
\pm \\
4.30^{\mathrm{b}, \mathrm{e}}\end{array}$ \\
\hline $\begin{array}{l}\mathrm{NO} \\
(\mu \mathrm{M})\end{array}$ & $\begin{array}{c}85.80 \\
\pm \\
4.76\end{array}$ & $\begin{array}{c}130.21 \\
\pm \\
11.56^{\mathrm{a}}\end{array}$ & $\begin{array}{c}83.87 \\
\pm \\
2.15^{\mathrm{b}}\end{array}$ & $\begin{array}{c}85.33 \\
\pm \\
3.41^{\mathrm{b}}\end{array}$ & $\begin{array}{c}75.43 \\
\pm \\
4.50^{\mathrm{b}}\end{array}$ & $\begin{array}{c}81.50 \\
\pm \\
6.62^{b}\end{array}$ \\
\hline
\end{tabular}

Data are expressed as mean \pm SEM $(n=6), a, b, c, d$ or $e$ : indicates significantly different from the control, myocardial infarction, vanillin $(150 \mathrm{mg} / \mathrm{kg}), \mathrm{MI}+$ vanillin $(150 \mathrm{mg} / \mathrm{kg})$ and vanillin $(300 \mathrm{mg} / \mathrm{kg})$ group, respectively at $P<0.05$ using one way ANOVA followed by Tukey-Kramer as a post hoc test.

Figure (1): Protective effects of vanillin on electro-cardio graphic changes in isopretrenolinduced myocardial infarction in rats

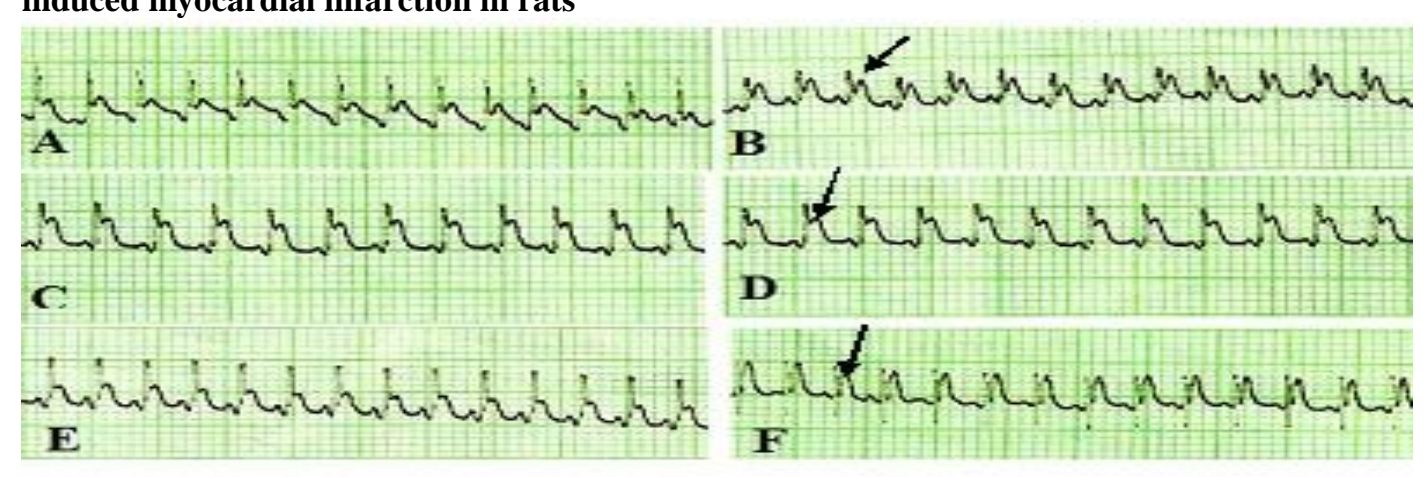


Figure (2): Protective effects of vanillin on renal function tests in isopretrenol- induced myocardial infarction in rats

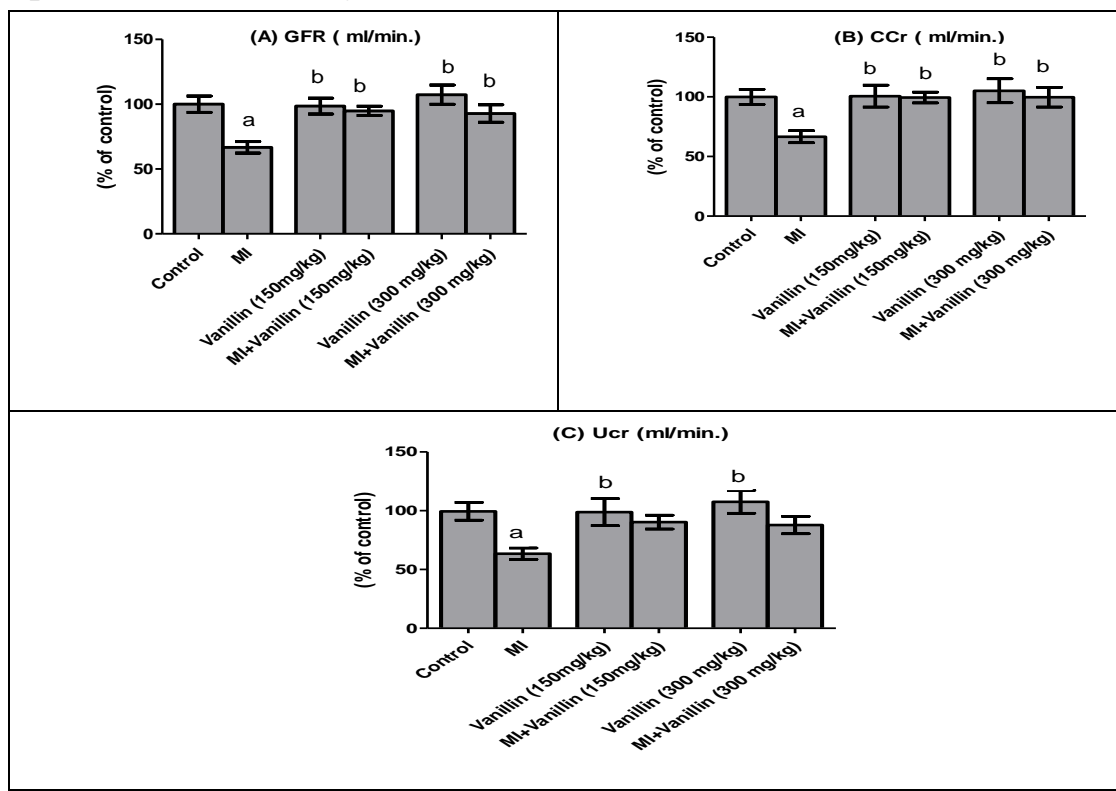

Figure (3): Protective effects of vanillin on cardiac histopathological changes in isopretrenolinduced myocardial infarction in rats
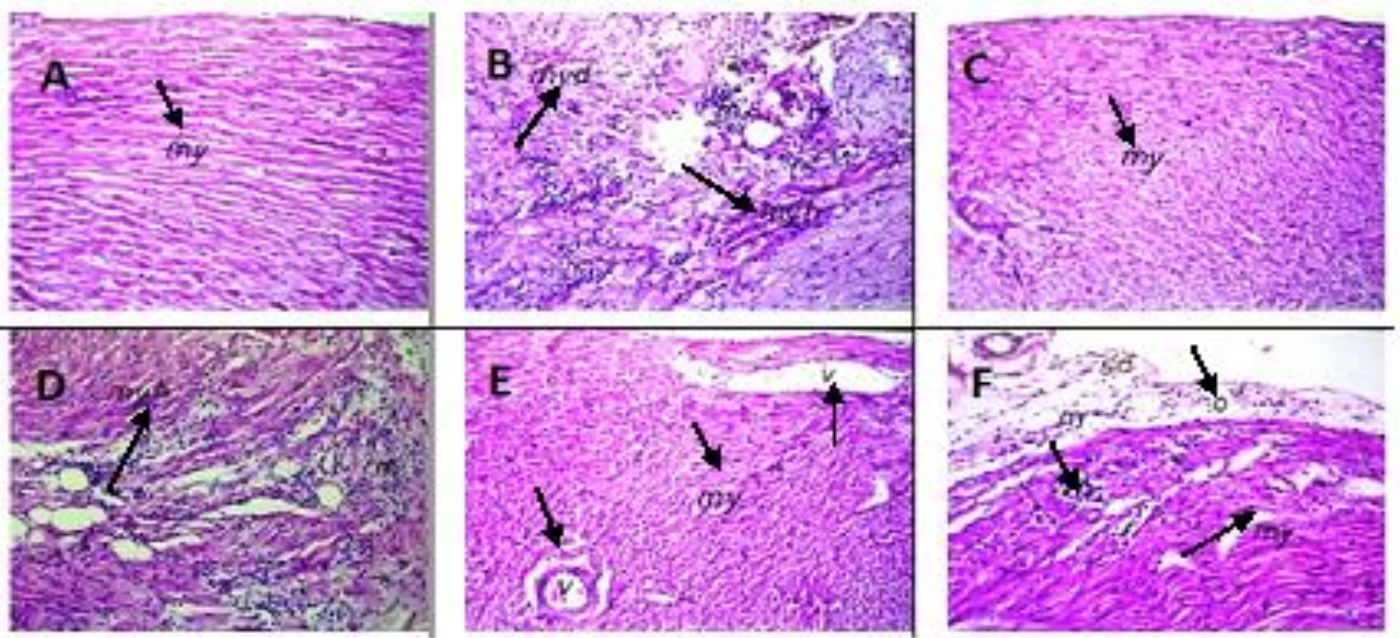

Figure (4): Protective effects of vanillin on renal histopathological changes in isopretrenolinduced myocardial infarction in rats
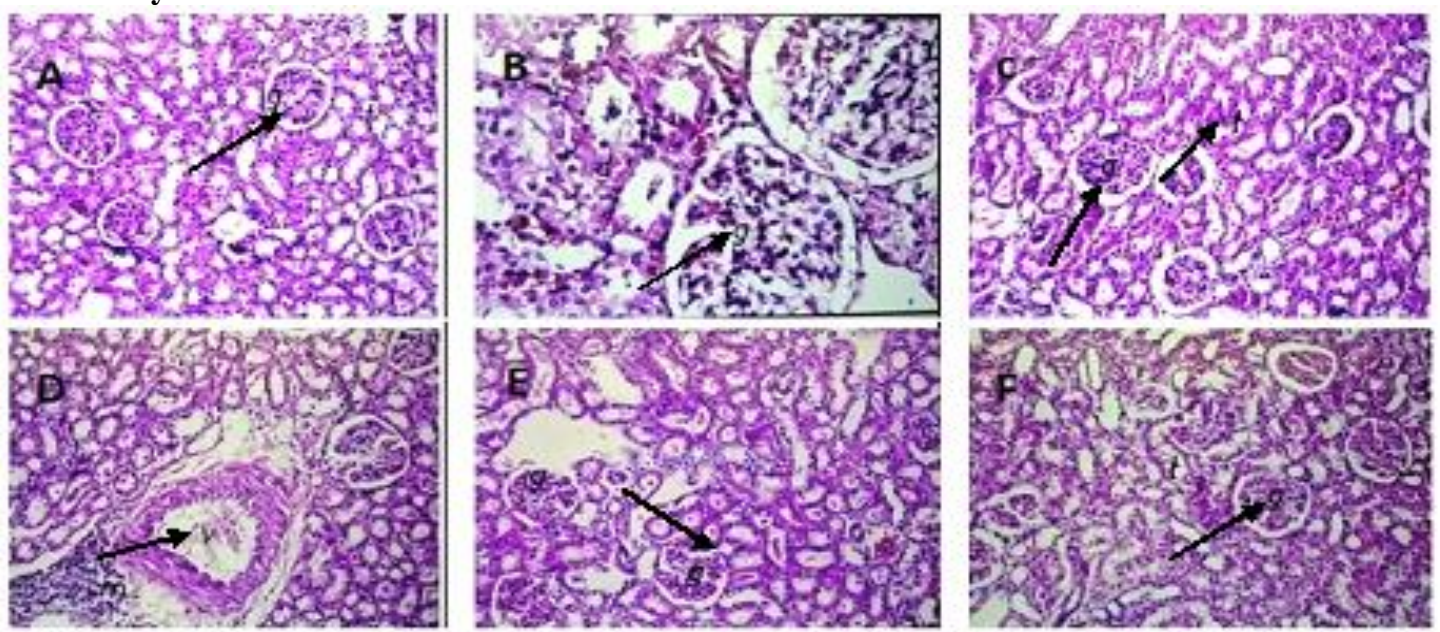


\section{Discussion}

The main criteria generally used for the definite diagnosis of MI are the evolving pattern of Electrocardiograph (ECG) abnormalities. Several studies have demonstrated that isoprenaline administration produce marked hemodynamic alterations manifested in the form of systolic or diastolic dysfunction and increased heart rate (Goyal et al., 2010). The adrenergic receptors stimulation due to overproduction of catecholamines is known to be a major cause of stress-induced cardiac dysfunction (Shao et al., 2013).

Beta-blocker therapy plays a major role in the pretreatment of cardiovascular diseases. They are used for their anti-ischemic, anti-arrhythmic and antihypertensive properties (Davel et al., 2014). Antiischemic action of beta-blockers decreases myocardial oxygen demand by reducing heart rate, cardiac contractility, and systolic blood pressure.

During the acute phase of MI, beta-blockers limit infarct size, reduce life-threatening arrhythmias, relieve pain and reduce mortality including sudden cardiac death (Srivastava et al., 2007). Vanidilol, newly synthesized from vanillin, is a vanilloid-type betaadrenoceptor blocker. It inhibits the tachycardiac effects induced by isoproterenol (Wu et al., 1994). Thus, vanillin can be used as a protective agent of MI as an adjuvant. In the present study, we noted a significant increase in heart rate and elevation of STsegments in isoprenaline-induced rats. The observed ST-segment elevation might be due to myocardial necrosis accelerated by isoprenaline, which is consistent with the observations of earlier reports (Patel et al., 2010).

Pretreatment with vanillin markedly inhibited isoproterenol-induced tachycardia and ST-segment elevation, suggestive of its cell membrane protecting effects. In addition, ECG monitoring of isoprenalinetreated rats showed positive T- wave and ST segment elevation coupled with marked decrease in $\mathrm{R}$ wave amplitude that reflect isoprenaline-induced myocardial ischemia and infarction. ECG pattern alterations by isoprenaline were previously demonstrated by previous investigators (Prince and Sathya, 2010). Pretreatment with vanillin produced a marked protection against isoprenaline-induced myocardial damage. Indeed, the suppression of MI by vanillin was reflected in the current investigation through the decrease in heart rate, suppression of ST-segment elevation and the marked increase in R wave amplitude upon ECG monitoring as compared with the isoprenaline group.

Rats treated with isoprenaline have been reported to undergo increase in heart weight. Hypertrophy of hearts as well as cardiomyocytes was also observed in our rat model. One postulate about increased heart wet weight is due to increase in water content and development of oedema in intramuscular spaces culminating in extensive necrotic changes and invasion of inflmmatory cells (Patel et al., 2010). Also, Cardiac hypertrophy was shown to be induced by isoprenaline via $\beta 1$ - adrenergic signaling (Patterson et al., 2004), but the pretreatment of MI group with vanillin improved these changes in heart index.

Myocardial cells contain several enzymes and macromolecules which on metabolic damage are released in the extracellular fluid and serve as diagnostic markers of myocardial injury (Ojha et al., 2008). The release of these enzymes reflects an alteration in the plasma membrane integrity and permeability in response to $\beta$-adrenergic stimulation (Goyal et al., 2010). Measuring of cTn-I level, CK$\mathrm{MB}$, and $\mathrm{LDH}$ activities are necessary to ascertain extent of myocardial injury. In the present study, isoprenaline administration caused a rise in the level of these cardiac diagnostic marker enzymes, due to leakage from the tissues to blood serum as a result of damaged or destroyed cardiomyocytes, as well as, the cells damaged because of insufficient supply of oxygen and oxidative damage of myocardium which render the cell membrane fragile, porous, or ruptured. The increased levels of these enzymes are indicative of severity of cell necrosis and isoprenaline mediated peroxidative myocyte injury (Heraldo et al., 2011). These observations are in accordance with previous studies performed on rats treated with isoproterenol (Wang et al., 2009).

Pretreatment of MI group with vanillin in both doses reduced the serum levels of cTn-I, CK-MB, and LDH activities compared to the histopathological changes in isoprenaline administered rats. The histopathological preservation and inhibition of lipid peroxidation due to antioxidant properties of vanillin (Makni et al., 2011), could be correlated with the reduced leakage of myocardial enzymes in serum. It can be inferred that vanillin might have preserved cell integrity and stabilized the myocardial membrane which restricts the leakage of these marker enzymes from the heart into blood.

Several studies have disclosed a complex relationship between cardiovascular and renal disease. Impaired renal function is detrimental for the heart (renocardiac interaction) both in clinical (Anavekar et al., 2004) and in experimental (Amann et al., 2003) settings. Impaired cardiac function is detrimental to the kidney (cardiorenal interaction), which is less well characterized in experimental settings.

Coexistence of renal and cardiac dysfunction, known as cardiorenal syndrome, has an adverse impact on clinical outcomes following AMI. Approximately one third of hospitalized AMI patients present with coexisting kidney dysfunction (Anavekar et al., 2004) and one fifth develop worsening renal function during hospitalization (Parikh et al., 2008). Lekawanvijit et al. (2012) demonstrated an experimental model of MI that worsening renal function which occur early post-MI, may be transient and is strongly related to activation of renal inflammatory-fibrosis pathways which leads to nonreversible functional impairment. Yujung et al. (2012) stated that vanillin has an anti-inflamatory effect, which can interpret the protective effect of 
vanillin in kidney diseases resulted after MI. In addition the protective effects of vanillin were evaluated against carbon tetrachloride $\left(\mathrm{CCl}_{4}\right)$-induced kidney damages in rats, as evidenced by increased plasma creatinine, urea and uric acid levels, increased lipid peroxidation (MDA). While pretreatment of rats with vanillin $(150 \mathrm{mg} / \mathrm{kg} / \mathrm{day}$, i.p. $)$, for 3 consecutive days before $\mathrm{CCl}_{4}$ injection, protected the kidneys against this damage (Makni et al., 2012).

The animal model of isoprenaline-induced myocardial injury recapitulates major metabolic and morphological changes similar to those occurring in human MI (Rona, 1985). Auto-oxidation of isoprenaline, which was used for induction of MI in our study, produces quinones, which react with oxygen to produce superoxide anions and hydrogen peroxide, leading to oxidative stress and depletion of the endogenous antioxidant system. Free radical scavenging enzymes, such as super oxide dismutase (SOD), CAT and RGH are the first line of cellular defense against oxidative injury, decomposing $\mathrm{O}_{2}$ and $\mathrm{H}_{2} \mathrm{O}_{2}$ before their interaction to form the more reactive hydroxyl radical (Wattanapitayakul and Bauer, 2001). The equilibrium between the enzymatic antioxidants and free radicals is an important process for the effective removal of oxidative stress in intracellular organelles (Senthila et al., 2004). However, in pathological conditions like MI, the generation of ROS can dramatically upset this balance with increased demand on the antioxidant defense system (Wu et al., 2009).

Vanillin(4-hydroxy-3-methoxybenzaldehyde), a compound isolated from the bean and pod of tropical vanilla orchid is widely used in the food and beverage industry and is responsible for the characteristic vanilla flavor (Oliveira et al., 2014). Besides its industrial and food application this compound has been the subject of several scientific investigations in the past few years, for the identification of antioxidant properties (Tai et al., 2011). Part of these biological properties can be attributed to the fact that vanillin is a phenolic compound. The antioxidant activity of phenols is attributed to their ability to scavenge free radicals (Surjadinata and Cisneros-Zevallos, 2012).

Myocardiac infarction (MI) is characterized by cardiac dysfunction, lipid peroxidation, altered activities of cardiac injury markers, and depletion of endogenous antioxidants (Ojha et al., 2012). Furthermore, it has also been documented that the heart is highly susceptible to oxidative stress compared with other tissues due to lower activity of antioxidant defense in the heart tissues (Hrelia et al., 2004). The endogenous antioxidant defense network constitutes enzymatic (SOD and CAT) and non-enzymatic (RGH) molecules to neutralize the ROS mediated tissue injury in oxidative stress (Oyanagui, 1984). SOD catalyzes the dismutation of superoxide anions to oxygen and $\mathrm{H}_{2} \mathrm{O}_{2}$, which is further detoxified by CAT to water. Among several mechanisms proposed for isoprenalineinduced MI, production of highly cytotoxic-free radicals through autooxidation and disturbed physiological balance between production of free radicals and antioxidative defense is widely accepted (Rathore et al., 1998). The decrease in activities of SOD and CAT following isoprenaline administration demonstrates overwhelming increase of free radicals, superoxide, and hydrogen peroxide which causes cellular injury. Vanillin pretreatment prevented decline of the myocardial CAT activities in isoprenaline administered rats.

Reduced glutathione ( $\mathrm{RGH})$ is a tripeptide which has a direct antioxidant function by reacting with superoxide radicals, peroxy radicals and singlet oxygen followed by the formation of oxidized RGH and other disulfides (Rathore et al., 1998). Thus, reduction in cellular RGH content could impair recovery after a short period of ischemia. In this study, isoprenaline administration was found to reduce the levels of RGH in cardiac tissue and the observation concurs with several earlier findings (Patel et al., 2010). Pretreatment with vanillin increased the level of $\mathrm{RGH}$ in the heart of isoprenaline-induced cardiotoxic rats when compared with individual treatment groups.

Lipid peroxidation has been defined as the oxidative deterioration of polyunsaturated lipid. It occurs constantly at a low level in most cellular biological systems. Oxygen-derived free radicals can react with lipids, if not blocked by sufficient antioxidant molecules, to form lipid peroxides which cause extensive damage (Tappel and Dillard, 1981). Since the major constituents of biological membranes are lipids, their peroxidation can lead to cell damage and death. A significant increase in the levels of lipid peroxidation products in isoprenaline -induced rats appear to be the initial stage to the tissue making it more susceptible to oxidative damage. Increased production of free radicals may be responsible for the observed membrane damage as evidenced by the elevated lipid peroxidation in terms of TBARS in the present study. The decrease in MDA level following pretreatment with vanillin can be ascribed to the enhanced activities of antioxidant status in myocardium. The ability of vanillin as a potent free radical scavenger and explain antioxidant may affect cardiac function and explicate its potential as a cardioprotective agent. The improved myocardial antioxidant status following vanillin treatment may presume to translate into the recovery of cardiac functions altered during isoprenaline -induced MI.

Nitric oxide (NO) level was also found to be increased in isoprenaline treated rats. It has been reported that inducible nitric oxide synthase (iNOS) expression and NO production increase in the myocardial infarcted heart (Pinto et al., 2007). $\beta$ Adrenergic stimulation also upregulated iNOS and significantly increases production of $\mathrm{NO}$ ( $\mathrm{Li}$ et al., 2006). Increased NO concentration creates a nitrosative stress in presence of other reactive oxygen species (ROS) such as superoxides and generates the powerful oxidant molecule peroxynitrite (ONOO-). In our study, vanillin pretreatment in both doses prevented the rise of NO level in isoprenaline treated rats. Antioxidants 
constitute the defense mechanism that limits the free radicals which initiate damage in tissues. A possible explanation for the decrease in $\mathrm{NO}$ production by vanillin may be mediated by its ability to inhibit iNOS expression through inhibition of nuclear factor-kappa B pathway, which further accounts for its antiinflammatory potential (Makni et al., 2011).

Histopathologic examination of isoprenalinetreated rats revealed edema, infiltration of inflammatory cells along with myocyte degeneration and renal impairment. These findings are in accordance with previous studies (Kannan and Quine, 2013). However, vanillin pretreatment to isoprenalinechallenged rats has shown resistance towards necrosis, edema, and inflammation. It also protected cardiomyocytes and renal cells from the deleterious effects of isoprenaline. Rats which received vanillin pretreatment exhibited a normal myocardial and renal histology, which is suggestive of the fact that vanillin at this dose does not produce any significant adverse effects on both myocardium and kidney tissues.

Regarding mortality, the resulting data from our study showed a mortality of $25 \%$ in the MI group. This value is consistent with data found in literature, pointing to the isoproterenol-induced MI as a cause of mortality in this experimental model. Acikel et al. (2005) reported a mortality rate of $33.33 \%$ in rats after receiving isoproterenol, while pretreatment of $\mathrm{MI}$ group with both doses of vanillin decreased rate of mortality.

\section{Conclusion}

In summary, the present study strongly demonstrates that a diversity of mechanisms may be responsible for the cardio- and reno- protective effects of vanillin. These beneficial potentials may be translated into improvement in heart weight/body weight ratio and reduced serum levels of myocyte marker enzymes along with restoration of antioxidants with concomitant reduction in reactive oxygen species in both cardiac and renal tissues. In addition to the improvement in renal biochemical parameters, vanillin significantly preserved the myocardial and renal histoarchitecture. In conclusion, the present study provides a scientific rationale of the utility value of vanillin. However, further well-controlled prospective clinical studies need to be performed to ascertain whether the present findings can be applied in the protection of human susceptible to ischemic heart diseases.

\section{References}

Aebi H. (1984): Methods Enzymol. 105, 121-126.

Acikel M, Buyukokuroglu ME, Erdogan F and et al. (2005): Protective effects of dantrolene against myocardial injury induced by isoproterenol in rats: biochemical and histological findings. Int J Cardiol. 98(3):389-394.

Agrawal Y, Sharma O, Shrivastava B and et al. (2014): Hesperidin produces cardioprotective activity via PPAR-pathway in ischemic heart disease model in diabetic rats. PLoS One 9 (11) e111212.

Akagi K, Hirose M, Hoshiya T and et al. (1995): Modulating effects of elagic acid, vanillin and quercetin in a rat medium term multi-organ carcinogenesis model. Cancer Lett 94:113121.

Amann K, Tyralla K, Gross M L, Schwarz U and et al. (2003): Cardiomyocyte loss in experimental renal failure: Prevention by ramipril. Kidney Int 63: 1708-1713.

Amin A P, Salisbury A C, McCullough P A and et al. (2012): Trends in the incidence of acute kidney injury in patients hospitalized with acute myocardial infarction. Arch Intern Med. 13,172(3):246-253.

Anavekar N S, McMurray J J, Velazquez E J and et al. (2004): Relation between renal dysfunction and cardiovascular outcomes after myocardial infarction. N Engl J Med 351: 1285-1295.

Banchroft J D, Stevens A and Turner D R (1996): Theory and practice of histological techniques. 4th ed, Churchil Livingstone, New York, London, San Francisco, Tokyo.

Bhagat B, Sullivan J M, Fischer V W and et al. (1976): cAMP activity and isoproterenol-induced myocardial injury in rats. Recent Adv Stud Card Struct Metab. 12:465-470.

Bloom S and Davis D L (1972): Calcium as mediator of isoproterenol-induced myocardial necrosis. Am J Pathol. 69(3):459-470.

Bythrow J D (2005): Vanillin as a medical plant. Semin Integr Med. 3:129-131.

Cheng W Y, Wu S L, Hsiang C Y and et al. (2008): Relationship between San-Huang-Xie-XinTang and its herbal components on the gene expression profiles in HepG2 cells. Am J Chin Med. 36: 783-797.

Davel A P, Brum P C, Rossoni L V (2014): Isoproterenol induces vascular oxidative stress and endothelial dysfunction via Gi $\alpha$-coupled $\beta 2$-adrenoceptor signaling pathway. PLoS One 9 (3): e91877.

Dhalla N S, Elmoselhi A B, Hata T and et al. (2000): Status of myocardial antioxidants in ischemiareperfusion injury. Cardiovasc Res. 47:446456.

Ellman G L (1959): Tissue sulfhydryl groups. Arch Biochem Biophys. 74: 214-226.Ertracht O, Malka A, Atar S and et al. (2014): The mitochondria as a target for cardioprotection in acute myocardial ischemia. Pharmacol and Thrap. 142 (1): 33-40.

Go AS, Chertow GM, Fan D and et al. (2004): Chronic kidney disease and the risks of death, 
cardiovascular events, and hospitalization. N Engl J Med. 351: 1305-1296.

Goyal S, Arora S, Bhatt $\mathrm{T}$ and et al. (2010): Modulation of PPAR- $\beta$ by telmisartan protects the heart against myocardial infarction in experimental diabetes. Chem-Biolog Interact. 185 (3): 271-280.

Griess P. Bemerkungen zu der abhandlung der H.H. Weselsky, Benedikt (1879): "Ueber einige azoverbindungen." Chem Ber. 12: 426-428.

Heraldo G, Nestor L, Rafael B and et al. (2011): Experimental model of myocardial infarction induced by isoproterenol in rats. Rev Bras Cir Cardiovasc. 26(3):469-476.

Hrelia S, Bordoni A, Angeloni C and et al. (2004): Nutritional interventions to counteract oxidative stress in cardiac cell. Ital J Biochem. 53: (4)157-163.

Ignarro L J, Balestrieri M L and Napoli C (2007): Nutrition, physical activity, and cardiovascular disease: an update. Cardiovasc Res. 73: 326340 .

Ithayarasi A P and Devi C S (1997): Effect of alphatocopherol on lipid peroxidation in isoproterenol induced myocardial infarction in rats. Indian J Physiol Pharmacol. 41(4):369376.

Kannan M M and Quine S D (2013): Ellagic acid inhibits cardiac arrhythmias, hypertrophy and hyperlipidaemia during myocardial infarction in rats. Metabolism 62:52-61.

Karl J, William J and Max L (1993): Anaesthetic effects of chloral hydrate, pentobarbitone and urethane in adult male rats. Laboratory Animals 27: 258-269.

Ket L H, Yazan L S, Ismail N and et al. (2010): Toxicology study of vanillin on rats via oral and intra-peritoneal administration. Food and Chemical Toxicology 49(1):25-30.

Kim HY, Yokozawa T, Nakagawa T and et al. (2004): Protective effect of gamma-aminobutyric acid against glycerol-induced acute renal failure in rats. Food Chem Toxicol. 42(12):2009-2014.

Kim JH (2012): Cardiovascular diseases and Panax ginseng: a review on molecular mechanisms and medical applications. J Ginseng Res. 36:16-26.

Lekawanvijit S, Kompa A R, Zhang Y and et al. (2012): Myocardial infarction impairs renal function, induces renal interstitial fibrosis, and increases renal KIM-1 expression: implications for cardiorenal syndrome. Am J Physiol Heart Circ Physiol. 302: H1884-H1893.

Lekston A, Kurek A, Tynior B (2009): Impaired renal function in acute myocardial infarction. Cardiol J. 16(5):400-406.
Li D, Qu L, Tao Y and et al. (2006): Inhibition of iNOS protects the aging heart against $\beta$ adrenergic receptor stimulation-induced cardiac dysfunction and myocardial ischemic injury. J Surg Res. 131(1): 64-72.

Makni M, Chtourou Y, Fetoui H, and et al. (2011): Evaluation of the antioxidant, antiinflammatory and hepatoprotective properties of vanillin in carbon tetrachloride-treated rats. Europ J Pharmacol. 668: 133-139.

Makni M, Chtourou Y, Garoui E M and et al. (2012): Carbon tetrachloride-induced nephrotoxicity and DNA damage in rats: protective role of vanillin. Hum Exp Toxicol. 31(8):844-852.

Murakami Y, Hirata A, Ito S and et al. (2007): Reevaluation of cyclooxygenas e-2-inhibiting activity of vanillin and guaiacol in macrop hages stimulated with lipopolysaccharide. Anticancer Res. 27:801-807.

Ojha S K, Nandave M, Arora S and et al. (2008): Chronic administration of Tribulus terrestris Linn. Extract improves cardiac function and attenuates myocardial infarction in rats. Int $\mathrm{J}$ Pharmacol. 4 (1):1-10.

Ojha S, Goyal S, Kumari S, and et al. (2012): Pyruvate attenuates cardiac dysfunction and oxidative stress in isoproterenolinduced cardiotoxicity. Exp and Toxicol Pathol. 64 (4): 393-399.

Oliveira C, Meurer Y, Oliveira M and et al. (2014): Comparative study on the antioxidant and antitoxoplasma. Activities of vanillin and its resorcinarene derivative. Molecules 19:58985912.

Oyanagui Y (1984): Reevaluation of assay methods and establishment of kit for superoxide dismutase activity. Anal Biochem. 142:290296.

Parikh C R, Coca S G, Wang Y and et al. (2008): Long-term prognosis of acute kidney injury after acute myocardial infarction. Arch Intern Med. 168: 987-995.

Patel V, Upaganlawar A, Zalawadia R and et al. (2010): Cardioprotective effct of melatonin against isoproterenol induced myocardial infarction in rats: A biochemical, electrocardiographic and histoarchitectural evaluation. Europ J Pharmacol. 644 (1-3): 160-168.

Patterson A J, Zhu W, Chow A and et al. (2004): Protecting the myocardium: a role for the $\beta 2$ adrenergic receptor in the heart. Crit Care Med. 32:1041-1048.

Pestel S, Krzykalla V and Weckesser G (2007): Measurement of glomerular filtration rate in the conscious rat. J Pharmacol Toxicol Methods. 56(3):277-289. 
Pinto V D, Cutini G J S, Sartorio C L and et al. (2007): Enhanced $\beta$-adrenergic response in rat papillary muscle by inhibition of inducible nitric oxide synthase aftr myocardial infarction. Acta Physiologica 190 (2): 111-117.

Prince P S and Sathya B (2010): Pretreatment with quercetin ameliorates lipids, lipoproteins and marker enzymes of lipid metabolism in isoproterenol treated cardiotoxic male Wistar rats. Eur J Pharmacol. 635:142-148.

Rathore N S, John S, Kale M and et al. (1998): Lipid peroxidation and antioxidant enzymes in isoproterenol induced oxidative stress in rat tissues. Pharmacol Res. 38(4): 297-303.

Rona G (1985): Catecholamine cardiotoxicity. J Molec and Cell Cardiology. 17 (4): 291-306.

Ruff CT and Braunwald E (2011): The evolving epidemiology of acute coronary syndromes. Nat Rev Cardiol. 8:140-147.

Senthila S, Veerappana RM, Ramakrishna RM and et al. (2004): Oxidative stress and antioxidants in patients with cardiogenic shock complicating acute myocardial infarction. Clin Chim Acta. 348:131-137.

Shao Y, Redfors B, Tang M S and et al. (2013): Novel rat model reveals important roles of $\beta$ adrenoreceptors in stress-induced cardiomyopathy. Int J Cardiol. 168(3): 19431950.

Singal PK, Kapur N, Dhillon KS and et al. (1982): Role of free radicals in catecholamine-induced cardiomyopathy. Can J Physiol Pharmacol. 60(11):1390-1397.

Srivastava S, Chandrasekar B, Gu Y and et al. (2007): Downregulation of CuZn-superoxide dismutase contributes to $\beta$-adrenergicreceptormediated oxidative stress in the heart. Cardiovasc Res. 74: 445-455.

Surjadinata B B and Cisneros-Zevallos L (2012): Biosynthesis of phenolic antioxidants in carrot tissue increases with wounding intensity. Food Chem. 134: 615-624.

Tai A, Sawano T, Yazama F and et al. (2011): Evaluation of antioxidant activity of vanillin by using multiple antioxidant assays. BBA-Gen Subjects 1810: 170-177.

Tappel AL and Dillard CJ (1981): In vivo lipid peroxidation: measurement via exhaled pentane and protection by vitamin E. Fed Proc. 40:174-178.
Tappia P S, Hata T, Hozaima L and et al. (2001): Role of oxidative stress in catecholamine-induced changes in cardiac sarcolemmal $\mathrm{Ca}^{2+}$ transport. Arch Biochem Biophys. 387 (1): 85-92.

Tullio F, Angotti C, Perrelli M G and et al. (2013): Redox balance and cardioprotection. Basic Res Cardiol. 108 (6): 392-397.

Uchiyama M and Mihara M (1978): Determination of malonaldhyde precursor in tissues by thiobarbituric acid test. Anal Biochem. 86: 271-282.

Visioli F, Borsani L and Claudio G (2000): Diet and prevention of coronary heart disease: The potential role of phytochemicals. Cardiovasc Res. 47:419-425.

Wang S B, Tian S, Yang F and et al. (2009): Cardioprotective effect of salvianolic acid A on isoproterenol-induced myocardial infarction in rats. Europ J Pharmacol. 615 (1-3): 125-132.

Wattanapitayakul SK and Bauer J A (2001): Oxidative pathways in cardiovascular disease Roles, mechanisms, and therapeutic implications. Pharmacol Therapeut. 89:187-206.

Wu B N, Hwang T L, Liao C F and et al. (1994): A new selective beta 1-adrenoceptor antagonist derived from vanillin. Biochem Pharmacol. 5, 48(1):101-109.

Wu J, Hecker JG and Chiamvimonvat N (2009): Antioxidant enzyme gene transfer for ischemic diseases. Adv Drug Deliver Rev. 61:351-363.

Yeager J C and Whitehurst M E (1982): Verapamil prevents isoproterenol induced cardiac failure in the rat. Life Sci. 30(3):299-306.

Yujung L B S, Kwon J B S, Khang G and et al. (2012): Reduction of inflammatory responses and enhancement of extracellular matrix formation by vanillin-incorporated poly (lactic-coglycolic acid). Scaffolds Tissue Engineering 18(A):19-20.

Zhang C, Li X, Lian L and et al. (2004): Antisickling effect of MX-1520, a prodrug of vanillin: an in vivo study using rodents. Br J Haematol. 125: 788-795.

Zhang T, Yang S and Du J (2014): Protective effects of berberine on isoproterenol-induced acute myocardial ischemia in rats through regulating HMGB1-TLR4 axis. Evidence-Based Complementary and Alternative Medicine (ID 849783): 1-8. 


\section{الملخص العربي}

\section{التأثيرات المحتملة الواقية للقلب والكلى لمادة الفانيلين على إحتشاء عضلة القلب بإستخدام الأيزوبروتونول فى الجرذان}

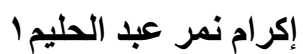

يستمر احتشاء عضلة القلب هو سبب وجود مشكلة صحية عامة رئيسية في العالم. ويعد الفانيلين هو مركب

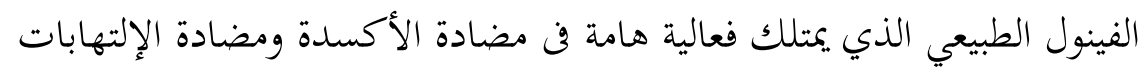

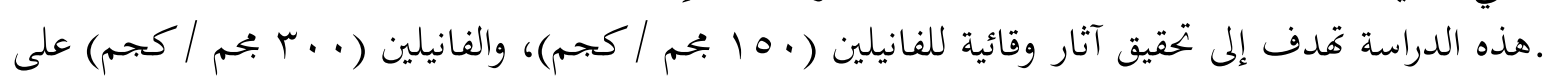

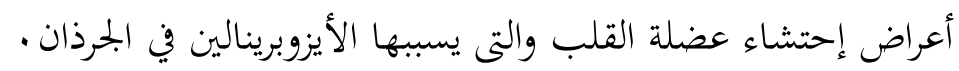

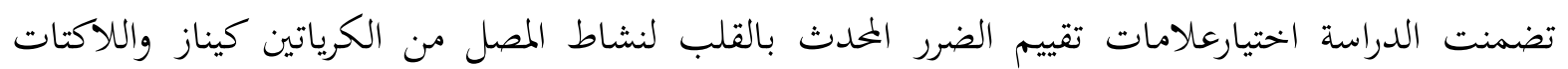

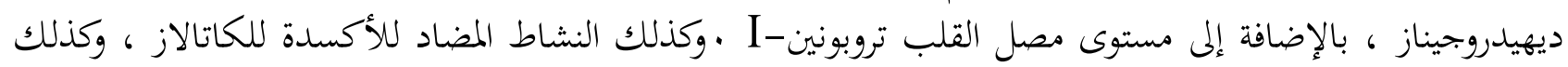

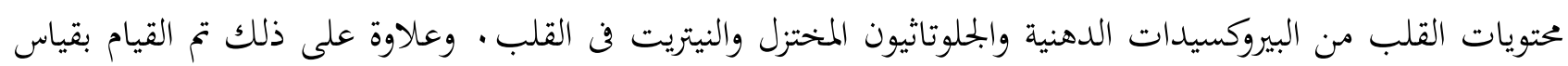

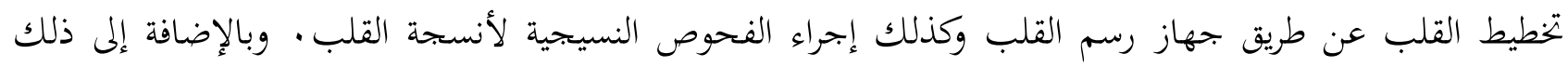

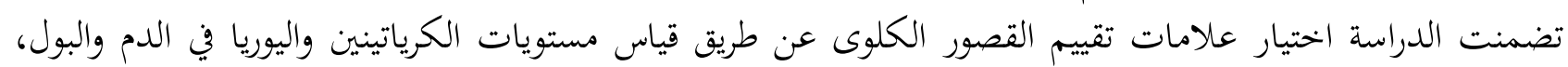

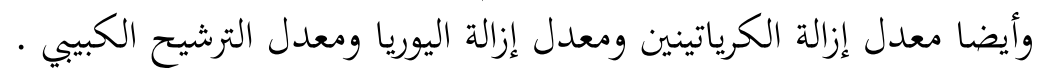

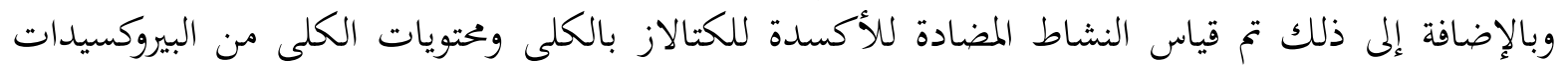

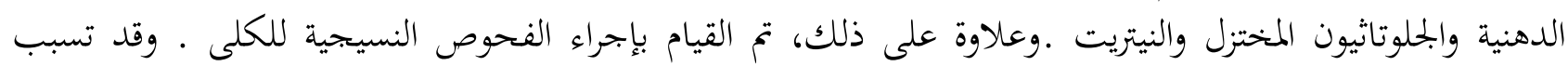

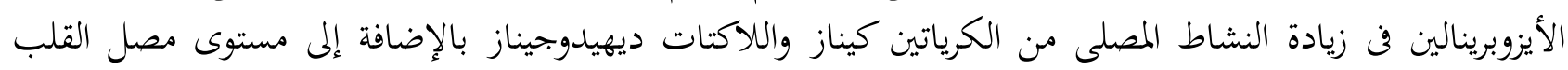

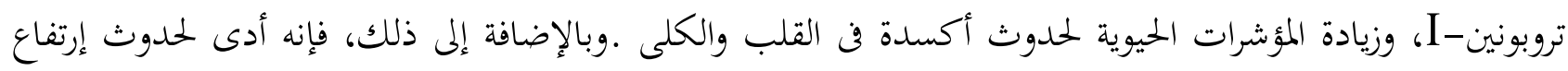

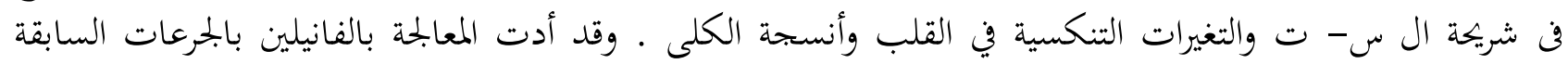

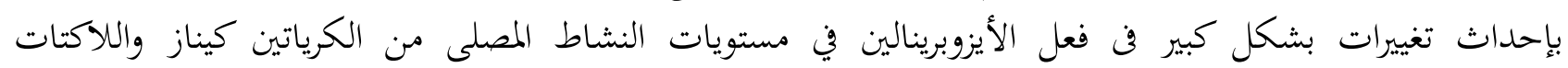

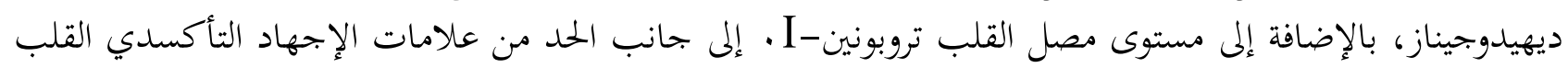

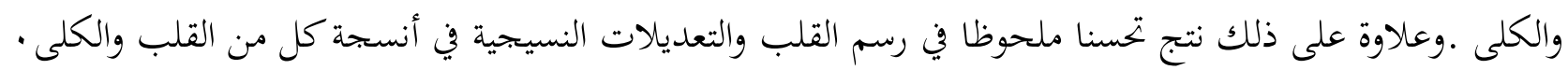

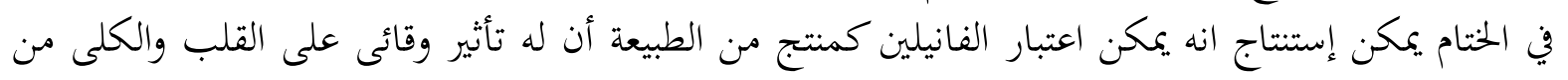

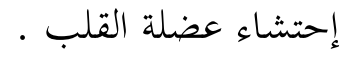

